\title{
The approach of emergency physicians to patients with acute renal colic
}

\author{
Acil servis doktorlarının akut renal kolikli hastaya yaklaşımı
}

\author{
Öner Bozan', Yavuz Onur Danacıoğlu², Mehmet Muzaffer İslam³ \\ 1 Department of Emergency Medicine, Prof. Dr. Cemil Tașcıoğlu City Hospital, İstanbul, Turkey \\ 2 Department of Urology, Bakirkoy Dr. Sadi Konuk Training and Research Hospital İstanbul, Turkey \\ 3 Department of Emergency Medicine, Ümraniye Training and Research Hospital, Istanbul, Turkey
}

Submitted (Geliş tarihi): 2021-10-29 Accepted (Kabul tarihi): 2021-12-27

\section{Correspondence / Yazışma}

Öner Bozan

Kaptan Paşa Mah. Okmeydanı Hospital No:25, 34384 Şişli, İstanbul / Turkey Email: onerbozan@gmail.com Tel: +905055121500

\section{ORCID \\ Ö.B. $\quad$ 0000-0002-4195-2601 \\ Y.O.D. 0000-0002-3170-062X \\ M.M.İ. $\quad$ 0000-0001-6928-2307}

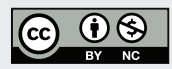

This work is licensed under a Creative Commons Attribution-NonCommercial 4.0 International License.

\section{Özet}

Amaç: Çalışmamızda acil servise başvuran ve akut renal kolik tanısı alan hastalarda acil tıp uzmanı ve asistanların tanı ve tedavi stratejilerini belirlemeyi amaçladik.

Gereç ve Yöntemler: Bu çalışmada acil tıp doktorlarına internet tabanlı kesitsel bir anket yapıldı. Ankette katılımcılara ait demografik verileri, acil serviste çalışma süreleri ve acil tıp uzmanı veya asistanı oldukları soruldu. Katılımcılara acil servise başvuran akut renal kolik hastalarında ilk tercih görüntüleme yöntemleri, tetkikler, hangi durumlarda üroloji konsültasyonu istedikleri, analjezik ve tedavi tercihleri soruldu.

Bulgular: Çalışmaya katılan 108 gönüllünün yaş ortancası $31(27-34,8)$ yıl olarak hesapland. Katılımciların \%60,2'i ( $\mathrm{n}=65)$ acil tıp asistanı, \%39,8'i $(n=43)$ acil tıp uzmanı olan çalışma grubunun acil serviste çalıştığı sürenin yıl cinsinden ortancası 4 (2-8) yıl olarak hesaplandı. Acil tıp uzmanı ve asistanlarının renal kolik ön tanısı ile acil servise başvuran hastalardaki yaklaşımları ile ilgili değişkenler açısından farkları incelendi. Non-steroidal antienflamatuvar ilaç (NSAID) verilmesi planlanan hastalarda seçilecek ilk ilaç, diklofenak ve diğer NSAID olarak dikotomize edildiğinde, uzmanların $34(\% 79,1)$ 'nün, asistanların ise 60 $(\% 92,3)$ 'inın ilk tercih olarak diklofenak seçtiği görülmüş ve gruplar arasında istatistiksel anlamlı fark saptandi.

\section{Abstract}

Objective: This study was conducted to describe the current diagnosis and treatment strategies of patients admitted to the emergency department and diagnosed with acute renal colic.

Material and Methods: In this study, an internet-based cross-sectional survey was administered to emergency medicine physicians. In addition to the participants' demographic data, such as age and gender, years of experience in the emergency medicine department, and whether they were a specialist or resident, the survey also inquired about their choices of imaging methods, laboratory tests, analgesic medications, and intravenous fluids, and tendency to refer patients to a urologist for a consultation.

Results: The median age of the 108 volunteers participating in the study was calculated as 31 (27 - 34.8) years and their years of experience as $4(2-8)$ years. More than half $(60.2 \%, n=65)$ of the participants were emergency medicine residents, while the remaining $39.8 \%(n=43)$ were emergency medicine specialists. The emergency medicine specialists and residents were compared in terms of the variables related to their approaches to patients presenting to the emergency department with a preliminary diagnosis of renal colic. The first choice of analgesic drugs was dichotomised as diclofenac and other non-steroidal anti-inflammatory drugs, with $34(79.1 \%)$ of the specialists and

Cite As: Bozan Ö, Danacioğlu YO, İslam MM. The approach of emergency physicians to patients with acute renal colic. New J Urol. 2022; 17(1):44-51. DOI: 10.33719/ yud.2022;17-1-1016256

This study was approved by the Ethics Committe of Health Sciences University, Bakırköy Training and Research Hospital (No: 2021-20/479, Date: October 18, 2021). All research was performed in accordance with relevant guidelines/regulations, and informed consent was obtained from all participants. 
Sonuç: Çalışmamızda acil tıp uzmanı ve asistanı arasında renal kolik görüntüleme yöntemi açısından benzer tercihler yapmasına rağmen birinci basamak tedavide acil tıp asistanları, acil tıp uzmanlarına kıyasla daha çok Diklofenak’ı tercih etmiștir.

Anahtar Kelimeler: Akut renal kolik, acil tıp, böbrek taşı.
$60(92.3 \%)$ of the residents reporting diclofenac as their first choice, and there was a statistically significant difference between the two groups.

Conclusion: In this study, the emergency medicine residents preferred diclofenac more than the emergency medicine specialists in primary care, although they had similar renal colic imaging methods preferences.

Keywords: Acute renal colic, emergency medicine, kidney stone.

\section{INTRODUCTION}

Hospital admissions for renal colic account for approximately $1 \%$ of all emergency presentations each year, and emergency department physicians provide care for this patient population at least once a day ( 1 , 2). Renal colic is a common urologic emergency in hospital emergency departments, caused by stones in the urinary system and associated with severe flank pain $(3,4)$. Costovertebral angle tenderness, abdominal pain, and haematuria are the main symptoms used to diagnose acute renal colic (5).

The emergency physician's role is to initiate appropriate treatment if the diagnosis is correct and refer the patients for consultation (2). The physician should intervene appropriately to relieve pain in treated patients and prevent complications associated with the etiological factor causing renal colic $(1,6)$. Emergency medicine specialists and residents may have different approaches to patients presenting to the emergency department. However, to our knowledge, no study compared emergency medicine specialists and residents in terms of their approach to patients with renal colic presenting to the emergency department.

This study aimed to define the diagnosis and treatment strategies of the emergency medicine specialist and residents in managing patients who presented to the emergency department and were diagnosed with acute renal colic.

\section{MATERIAL AND METHODS}

The study included 121 emergency medicine specialists. Six did not complete the questionnaire, and seven were excluded because they were not emergency medicine residents or specialists. As a result, the study was completed with 108 participants.

We used the Google Forms platform for this cross-sectional study and designed an online survey with 11 questions. The study was designed according to the Checklist Rules for Reporting Results of Electronic Surveys on the Internet (CHERRIES) (7). Participants who completed the survey between October 1, 2021, and October 15, 2021, were included in the study and divided into two groups as emergency medicine residents and specialists (Ethics committee approval number: 2021-479).

A web-based cross-sectional survey was administered to emergency medicine physicians in this study. The participants were informed about the study's aims with a brief presentation, and their electronic informed consent was obtained before the study began. They were also informed that they could withdraw from the survey without giving any reason, and in that case, their data would not be used. No personal information was collected during the survey to allow participants to be identified. The survey took approximately 5 minutes to complete and included questions related to demographic data, such as the participant's age and gender, years of experience in the emergency medicine department, and whether they had an emergency medicine specialist or resident. The participants were also asked about the first-choice imaging modality in patients presenting to the emergency department with acute renal colic, laboratory tests they requested at the time of admission, indications they used to refer patients for urological consultation, analgesics they preferred, 
and whether and how often they administered saline to patients. The findings obtained from the survey were compared between the groups. Due to the survey's design, the participants needed to answer all the questions to ensure successful participation.

\section{Statistical Analysis}

SPSS (IBM Corp. Released 2019. IBM SPSS Statistics for Windows, Version 26.0. Armonk, NY: IBM Corp.) was used for data analyses. The conformity of continuous data to the normal distribution was analyzed using the Shapiro-Wilk test. Continuous data that did not conform to the normal distribution were expressed as median (25\%-75\% quartile) values and categorical data as frequency and percentages. Paired-group comparisons were performed using the Mann-Whitney U test for continuous data that did not conform to the normal distribution. Group comparisons for categorical data were undertaken using the chi-square test, with Fisher's exact test conducted when necessary. The statistically significant level was accepted as $\mathrm{p}<0.05$.

\section{RESULTS}

The mean age of the 108 volunteers who participated in the study was 31 (27-34.8) years. In the study group, $60.2 \%(n=65)$ of the participants were emergency medicine residents, and $39.8 \%(n=43)$ were emergency medicine specialists. The median length of service in the emergency department was calculated as
4 (2-8) years. The primary demographic characteristics of the participants and their responses to the survey questions are summarized in Table 1.

The emergency medicine specialists and their residents were compared in terms of variables related to their approach to patients presenting to the emergency department with a pre-diagnosis of renal colic. The first choice of analgesic drugs was dichotomised as diclofenac and other non-steroidal anti-inflammatory drugs (NSAIDs), with 34 (79.1\%) of the specialists and $60(92.3 \%)$ of the residents reporting diclofenac as the first choice, and there was a statistically significant difference between the two groups ( $\mathrm{p}=0.045)$.

When comparing the frequency of C-reactive protein (CRP) requests between the two groups, it was found that 21 of the specialists $(48.8 \%)$ and 48 of the residents (73.8\%) requested this test, and the difference was statistically significant $(\mathrm{p}=0.008)$. There was a statistically significant difference between the two groups in relation to the frequency of blood gas requests, [3 (7\%) among the specialists and 18 (27.7\%) among the residents] $(\mathrm{p}=0.008)$. The frequency of albumin requests also statistically significantly differed between the specialists $(0 \%)$ and residents $(\mathrm{n}=7,10.8 \%)(\mathrm{p}=$ 0.025). There was no statistically significant difference between the two groups concerning the remaining variables. The primary outcome measures are summarized in Table 2.

Table 1. Baseline characteristics of the sample

\begin{tabular}{ll}
\hline $\mathbf{n}=\mathbf{1 0 8}$ & Median (25-75\% quartile)/n (\%) \\
\hline Age & $31(27-34.8)$ \\
Gender (male) & $67(62)$ \\
\hline Title & \\
\hline Emergency medicine resident & $65(60.2)$ \\
Emergency medicine specialist & $43(39.8)$ \\
Years of experience & $4(2-8)$ \\
Emergency medical residents & $2(1-3.5)$ \\
Emergency medical specialists & $9(6-11)$ \\
\hline
\end{tabular}


What is the first imaging method you would request in patients with suspected renal colic?

X-ray

$13(12)$

Abdominal CT

$46(42.6)$

Ultrasonography

$49(45.4)$

Which laboratory tests would you request?

Complete urinalysis

$107(99.1 \%)$

Complete blood count

$80(74.1 \%)$

Creatinine

$89(82.4 \%)$

Urea

$84(77.8 \%)$

CRP

$72(66.7 \%)$

Blood electrolytes

$53(49.1 \%)$

Blood gas analysis

$21(19.4 \%)$

Albumin

$4(3.7 \%)$

What would be the first analgesic treatment protocol you would choose?

$\begin{array}{ll}\text { NSAID } & 43(39.8 \%) \\ \text { NSAID + opioid } & 65(60.2 \%)\end{array}$

If you were to give the patient an NSAID, what would be your first choice?

Diclofenac

$94(87 \%)$

Etodolac

2 (1.9\%)

Ketorolac

4 (3.7\%)

Ibuprofen

3 (2.8\%)

Other

5 (4.6\%)

If you were to give the patient opioids, what would be your first choice?

\begin{tabular}{ll}
\hline Fentanyl & $40(37 \%)$ \\
Morphine & $6(5.6 \%)$ \\
Tramadol & $62(57.4 \%)$ \\
\hline Do you prefer to use an isotonic solution? & $1(0.9 \%)$ \\
\hline Never & $20(18.5 \%)$ \\
Rarely & $35(32.4 \%)$ \\
Sometimes & $37(34.3 \%)$ \\
Often & $15(13.9 \%)$ \\
Always & \\
\hline In which situations would you request a urology consultation? & $46(42.6 \%)$ \\
\hline Resistant flank pain & $93(86.1 \%)$ \\
Decreased urine output & $52(48.1 \%)$ \\
Presence of fever & $2(1.9 \%)$ \\
\hline Newly diagnosed renal colic &
\end{tabular}

CT: computed tomography, CRP: C-reactive protein, NSAID: non-steroidal anti-inflammatory drug 
Table 2. Comparison of the approaches of the emergency medicine residents and specialists to patients presenting with renal colic Emergency medicine Emergency medicine p-value resident, $\mathbf{n}(\%)$ specialist, $\mathbf{n}(\%)$

What is the first imaging method you would request in patients

with suspected renal colic?

\begin{tabular}{lll}
\hline X-ray & $8(12.3)$ & $5(11.6)$ \\
Abdominal CT & $28(43.1)$ & $18(41.9)$ \\
Ultrasonography & $29(44.6)$ & $20(46.5)$
\end{tabular}

What would be the first analgesic treatment protocol you would choose?

\begin{tabular}{lll}
\hline NSAID & $27(41.5)$ & $16(37.2)$ \\
NSAID + opioid & $38(58.5)$ & $27(62.8)$ \\
\hline
\end{tabular}

If you were to give the patient an NSAID, what would be your first choice?

\begin{tabular}{|c|c|c|c|}
\hline Diclofenac & $60(92.3)$ & $34(79.1)$ & 0.045 \\
\hline Other NSAIDS & $5(7.7)$ & $9(20.9)$ & \\
\hline \multicolumn{4}{|c|}{$\begin{array}{l}\text { If you were to give the patient opioids, what would be your first } \\
\text { choice? }\end{array}$} \\
\hline Fentanyl & $27(41.5)$ & $13(30.2)$ & 0.060 \\
\hline Morphine & $1(1.5)$ & $5(11.6)$ & \\
\hline Tramadol & $37(56.9)$ & $25(58.1)$ & \\
\hline \multicolumn{4}{|c|}{ Do you prefer to use an isotonic solution? } \\
\hline Rarely & $12(18.5)$ & $9(20.9)$ & 0.247 \\
\hline Sometimes & $25(38.5)$ & $10(23.3)$ & \\
\hline Often & $28(43.1)$ & $24(55.8)$ & \\
\hline \multicolumn{4}{|c|}{ In which situations would you request a urology consultation? } \\
\hline Resistant flank pain & $29(44.6 \%)$ & $17(39.5 \%)$ & 0.601 \\
\hline Decreased urine output & $54(83.1 \%)$ & $39(90.7 \%)$ & 0.262 \\
\hline Presence of fever & $30(46.2 \%)$ & $22(51.2 \%)$ & 0.610 \\
\hline Newly diagnosed renal colic & $2(3.1 \%)$ & $0(0 \%)$ & 0.516 \\
\hline \multicolumn{4}{|c|}{ Which laboratory tests would you request? } \\
\hline Complete blood count & $49(75.4 \%)$ & $31(72.1 \%)$ & 0.702 \\
\hline CRP & $48(73.8 \%)$ & $21(48.8 \%)$ & 0.008 \\
\hline Blood urea nitrogen & $51(78.5 \%)$ & $33(76.7 \%)$ & 0.834 \\
\hline Creatinine & $52(80 \%)$ & $37(86 \%)$ & 0.419 \\
\hline Blood electrolytes & $36(55.4 \%)$ & $17(39.5 \%)$ & 0.107 \\
\hline Complete urinalysis & $65(100 \%)$ & $42(97.7 \%)$ & 0.398 \\
\hline Blood gas analysis & $18(27.7 \%)$ & $3(7 \%)$ & 0.008 \\
\hline Albumin & $7(10.8 \%)$ & $0(0 \%)$ & 0.025 \\
\hline
\end{tabular}

CT: computed tomography, CRP: C-reactive protein, NSAID: non-steroidal anti-inflammatory drug 


\section{DISCUSSION}

This national survey study aimed to determine the differences in the approaches of emergency medicine specialists and residents in patients with renal colic. The results revealed that the emergency medicine residents and emergency medicine specialists differed in their approaches to diagnosing and managing patients with renal colic. There is no other study in Turkey that questioned the approach of emergency department physicians to patients with renal colic and determined the differences in these approaches between specialists and residents considering many articles published in Turkish and other languages, to our knowledge.

Renal colic due to obstruction caused by a stone places a significant burden on health systems and emergency services worldwide $(8,9)$. Two percent of adult patients admitted to the emergency department constitute those with suspected renal colic. The incidence of these patients has doubled in the last two decades (10). Essential steps in managing patients with renal colic are to diagnose a complete obstructive stone, relieve severe pain leading to nausea and vomiting, decide on intervention by establishing the negative findings of the clinical picture, and safely discharge the patient by demonstrating adequate urine flow $(8,9)$. Renal colic caused by an obstructive stone is usually manifested by the sudden onset of severe and sharp, local or radiating pain, often accompanied by nausea, vomiting, and urinary symptoms (8).

After a general examination of these patients, imaging techniques are essential in diagnosis (10). The European Association of Urology (EAU) guidelines state that the first imaging procedure should be ultrasonography (US) if urolithiasis is suspected. However, for patients with treatment-resistant pain and in cases where another diagnosis is suspected, abdominal computed tomography (CT) without contrast enhancement is recommended (11). In a study by Smith et al., it was found that the rates of complications, serious adverse events, readmission to the emergency department, and hospitalization were similar between the groups in which US or CT was performed as the first imaging modality among the patients presenting to the emergency department (12). Our study found that the pre- ferred imaging modalities in patients admitted to the emergency department were US, CT, and X-ray of the urinary system in order of frequency. We also determined no significant difference between the residents and specialists regarding their preference for these imaging modalities.

In renal colic, reducing severe acute pain is one of the main steps in managing the patient. Essential factors in deciding on the first choice of analgesic therapy include the safety, efficacy, cost, and availability of a drug in addition to the patient and clinician preferences (13). NSAIDs with proven efficacy in treating renal colic, acting through inhibition of prostaglandin synthesis, constitute the first-line therapy (14). Although the efficacy of NSAIDs has been proven, many clinicians now prefer opioids as the first step in pain management. The use of opioids is common today due to their advantages of dose titration and avoiding the possible risks of renal failure and gastrointestinal bleeding of NSAIDs (13). In our study, $39.8 \%$ of the emergency medicine physicians preferred NSAIDs alone, while $60.2 \%$ preferred NSAIDs and opioids together. It was determined that the emergency medicine residents and specialists had similar preferences in first-line treatment, but they preferred diclofenac more as an NSAID. However, studies have shown that high-dose dipyrone $(2 \mathrm{~g})$ is more effective than diclofenac (15). Although there are differences in the usage or preference rates, NSAIDs can reduce pain as much as opioids (13).

There are several situations where discharge or a conservative approach is not warranted, and the patient's immediate referral to a urology clinic for consultation is required due to complete or incomplete ureteral obstruction. Urology clinic consultation should be performed in patients with solitary or transplanted kidneys, pyelonephritis or sepsis, and general condition disorder, which may endanger the patient's life or cause irreversible damage to the kidney (8). Our study determined that urology consultation was requested in patients presenting with renal colic in cases of decreased urine output, accompanying fever, persistent flank pain, and newly diagnosed renal colic. There was no difference between the emergency medicine residents and specialists regarding clinical behavior patterns. 
Biochemical evaluation is similar for all patients with stones. The EAU guidelines recommend C-reactive protein (CRP), electrolyte, complete blood count, and creatinine evaluation in patients presenting to the emergency department with renal colic (11). CRP, a non-specific acute phase reactant, is considered a good marker for emergency urinary diversion and surgical intervention in patients admitted to the emergency department $(16,17)$. This study determined that patients who presented to the emergency department with renal colic were evaluated for complete urinalysis, creatinine, urea, hemogram, CRP, blood electrolytes, blood gas, and albumin in order of frequency. A CRP test was requested by $73.8 \%$ of the emergency medicine residents and $48.8 \%$ of the emergency medicine specialists as the first application. In addition, the rates of blood gas and albumin request rates as laboratory tests were higher among the emergency medicine residents than among the specialists. While $10.8 \%$ of the emergency medicine residents requested an albumin test, none of the specialists used albumin as a diagnostic test in patients presenting with renal colic. Although various guidelines define diagnostic tests requested in patients presenting with renal colic, the lack of consensus on this issue leads to different management styles. However, the use of complete blood count, creatinine, and blood electrolytes when necessary can provide the necessary information concerning the clinical status of patients (8).

Our study has certain limitations, including the relatively small number of participants, stratification of residents by years of education, and data is based on the participants' self-reports.

\section{CONCLUSION}

In this study, we obtained data from the emergency medicine specialist and residents working in reference centres to which patients present with acute renal colic. We determined that the emergency medicine residents and emergency medicine specialists had different approaches to diagnosing and treating patients with renal colic. We determined that the imaging method preferences of the two groups were similar. However, the emergency medicine specialists had a different approach than the residents in terms of using NSAIDs as first-line treatment. In addition, there were differences between the two groups concerning the laboratory tests performed on patients with renal colic. There is a need for multicentre prospective clinical studies to provide extensive and more precise data.

\section{Conflict of interest}

The authors declare to have no conflicts of interest.

\section{Financial Disclosure}

The authors declared that this study has received no financial support.

\section{Informed Consent}

Informed consent was obtained from all individual participants included in the study.

\section{Ethical Approval}

The study was approved by the Ethics Committe of Health Sciences University, Bakırköy Training and Research Hospital (No: 2021-20/479, Date: October 18, 2021) and written informed consent was received from all participants. The study protocol conformed to the ethical guidelines of the Helsinki Declaration.

\section{Author Contributions}

Conception and design; ÖB, YOD, Data acquisition; ÖB, MMİ, Data analysis and interpretation; ÖB, MMİ, Drafting the manuscript; ÖB, YOD, MMI, Critical revision of the manuscript for scientific and factual content; ÖB, YOD, MMİ, Statistical analysis; ÖB, MMİ, Supervision; ÖB, YOD, MMİ.

\section{REFERENCES}

1. Brown J. Diagnostic and treatment patterns for renal colic in US emergency departments. Int Urol Nephrol. 2006;38(1):87-92.

2. Phillips E, Kieley S, Johnson EB, et al. Emergency room management of ureteral calculi: current practices. J Endourol. 2009;23(6):1021-1024.

3. Ay MO, Akkan A, Acehan S, et al. Acil Serviste Renal Kolikli Hasta Yönetimi. Arşiv Kaynak Tarama Dergisi. 2014;23(2):1-17.

4. Corbo J, Wang J. Kidney and ureteral stones. Emerg Med Clin North Am. 2019;37(4):637-648. 
5. Aydin ME, Tekin E, Ahiskalioglu EO, et al. Erector spinae plane block vs non-steroidal anti-inflammatory drugs for severe renal colic pain: A pilot clinical feasibility study. Int J Clin Pract 2021;75(3):e13789.

6. Cotta BH, Nguyen V, Sur RL, et al. Opiates prescribed for acute renal colic are associated with prolonged use. World J Urol. 2021;39(6):2183-2189.

7. Eysenbach G. Improving the quality of Web surveys: the Checklist for Reporting Results of Internet E-Surveys (CHERRIES). J Med Internet Res. 2004;6(3):e132.

8. Leveridge M, D’Arcy FT, O'Kane D, et al. Renal colic: current protocols for emergency presentations. Eur J of Emerg Med. 2016;23(1):2-7.

9. Minhaj FS, Hoang-Nguyen M, Tenney A, et al. Evaluation of opioid requirements in the management of renal colic after guideline implementation in the emergency department. Am J Emerg Med. 2020;38(12):2564-2569.

10. Alabousi A, Patlas MN, Mellnick VM, et al. Renal colic imaging: myths, recent trends, and controversies. Can Assoc Radiol J. 2019;70(2):164-71.

11. Türk C, Petř́k A, Sarica K, et al. EAU guidelines on diagnosis and conservative management of urolithiasis. Eur Urol. 2016;69(3):468-74.
12. Smith-Bindman R, Aubin C, Bailitz J, et al. Ultrasonography versus computed tomography for suspected nephrolithiasis. N Eng J Med. 2014;371(12):1100-10.

13. Pathan SA, Mitra B, Cameron PA. A systematic review and meta-analysis comparing the efficacy of nonsteroidal anti-inflammatory drugs, opioids, and paracetamol in the treatment of acute renal colic. Eur Urol. 2018;73(4):58395.

14. Holdgate A, Pollock T. Systematic review of the relative efficacy of non-steroidal anti-inflammatory drugs and opioids in the treatment of acute renal colic. BMJ. 2004;328(7453):1401.

15. Afshar K, Jafari S, Marks AJ, et al. Nonsteroidal anti-inflammatory drugs (NSAIDs) and non-opioids for acute renal colic. Cochrane Database Syst Rev. 2015 (6).

16. Angulo JC, Gaspar MJ, Rodríguez N, et al. The value of C-reactive protein determination in patients with renal colic to decide urgent urinary diversion. Urol 2010;76(2):301-6.

17. McSorley S, Drury M, Majumdar P, et al. C-reactive protein to predict the need for surgical intervention in acute renal colic. J Clin Urol. 2014;7(6):380-3. 